\title{
On Solid Promotion of Network Construction for College Ideological and Political Education
}

\author{
Sijie Wang \\ Chongqing Technology \& Business Institute, Chongqing, 401520, China
}

Key words: College ideological and political education, Network, Construction measures.

\begin{abstract}
College ideological and political education has important significance for the development of college students and teachers, so relevant management department must pay attention to the application of information technology, promote network construction for ideological and political education, sum up relevant work experience, active carry out all kinds of education work and lay a solid foundation for follow-up development.
\end{abstract}

\section{Introduction}

College ideological and political management department must formulate a sound work system for education network construction, innovate relevant work modes, improve work quality, enhance the effect of college ideological and political education and utilize all kinds of advanced network construction methods to boost the quality of college ideological and political education.

\section{Summarizing work experience about network construction for college ideological and political education}

With the popularization of network information technology in China, the application of modern information technology becomes the most important system in people's life, and it is beneficial to people's production and work. In recent years, Chinese colleges have started to apply network information technology in ideological education work, which can effective boost information dissemination speed, reduce the time for ideological and political education, enhance the resolving ability and wrong information resistance ability of ideological and political education workers and give play to the function of network information technology.

Under the condition of educational reform in China, the education sector begins to boost network construction for ideological and political education and requires Party building workers to actively construct college ideological and political network according to relevant rules and fuse thought, culture and information so as to overall improve the effectiveness of network construction for ideological and political education. So, colleges must sum up relevant work experience in ideological education work, discover the problems in time, take active measures to solve problems and improve the quality of college ideological and political education.

Firstly, college ideological and political education organization should utilize sound investigation method to sum up the rules and features of network construction for ideological and political education, refer to successful experience, scientifically implement various researches, carry out comprehensive analysis and improve scientificity and rationality of college ideological and political education.

Secondly, thorough network construction mechanism for ideological and political education should be explored. College ideological and political education workers must actively explore all kinds of sound mechanisms in practical work to guarantee improvement of work quality, reduction of various problems, standardization of network construction behaviors and enhancement of work effect. 
Meanwhile, special campus network should be established, and special leaders should be appointed to manage it. As well, college network management center should be set up, and high-quality technical talents should be provided to guarantee security and reliability of network construction for college ideological and political education. At the same time, it is also required to publish network information, improve network management rules, improve the quality of cultural information education and scientifically carry out management and monitoring activity.

Thirdly, healthy campus network culture should be built. During constructing the campus network some colleges have established the ideological and political subjects, and rationally standardized them. Colleges may integrate educational resources in the society, expand education service channels, reduce various education problems, improve the work efficiency of moral and political cultivation, enrich campus network culture, create favorable educational environment and cultural environment, carry forward education network, resist all kinds of information harmful to students' development and promote the work quality of network construction for ideological and political education.

Fourthly, network education team building should be enhanced. In the network construction for college ideological and political education, relevant management personnel must build a high-quality talent team and guarantee improvement of network construction efficiency, reduction of various problems and promotion of work quality. Firstly, relevant departments must regard Deng Xiaoping Theory as the guidance, establish the idea of advancing with the times according to ideological requirement of three-representative thought, create good network base, cultivate technical talents with innovation ability and guarantee improvement of college ideological and political education and promotion of work quality. Secondly, during constructing the network for ideological and political education, colleges must utilize sound system to carry out education management for talents, train them for professional knowledge and advanced technology by stages, and make them better grasp campus culture construction skills and improve campus network construction quality. Finally, college ideological and political education management department should take effective actions to construct campus network, utilize high-quality talent team to expand network construction channel, improve work quality and reach the expected purpose.

Fifthly, the department responsible for network construction for college ideological and political education needs to scientifically carry out all kinds of education work, discover the problems in time and take effective measures under the uniform leadership of the Party committee. Firstly, it is required to solve the problem of network imbalance, deem network construction as strategic deployment scheme, deeply sum up the features and rules of network construction work, and implement relevant work in a scientific way. Secondly, for the problem that there is lack of theme network content, relevant management personnel need to expand ideological education information channel, accelerate ideological education speed, utilize sound work style for guidance, guarantee information processing timeliness and effectiveness and evade all kinds of bad information. Thirdly, in terms of the policy, relevant management departments in colleges should actively explore various guarantee policies, cooperate with the government sector, solve network construction problem on the whole, rationally improve work quality and reach the expected network construction purpose. Since network construction for college ideological and political education is still in the initial stage in China, it is rehired to actively explore all sorts of construction modes and experience in practical construction process, improve work quality and reduce various problems in work ${ }^{[1]}$.

\section{Properly exploiting a new situation of network construction for college ideological and political education}

During the network construction for ideological and political education, colleges must exploit a new situation, reduce various problems in work and boost long-term development of colleges.

Firstly, the advantage of network information technology should be fully exerted. Relevant management department of colleges must actively apply network information technology, establish correct idea and cognition, and actively improve ideological and political work style through technical popularization. Under the situation of social political diversification and information 
development, relevant management department of colleges must attach importance to modern socialist construction, overall reform the mode of college ideological and political education, expand education work channel, meet new work requirements and guarantee implementation of ideological and political education with network information technology. Meanwhile, colleges also should pay attention to construction of network software and hardware facilities, introduce computer equipment and other hardware facilities, regard students and teachers as the subjects to carry out effective reform, solve various problems in network construction, improve development efficiency and enhance work effect of college service management ${ }^{[2]}$.

Internet is the latest communication technology in modern social development, with the advantages of fast communication speed and large capacity. It can expand the coverage and improve the quality of education. Firstly, college management personnel need to utilize network information sharing mode to offer sufficient and feasible educational resources for ideological education work. Secondly, technical personnel need to give full play to interactive and open functions of network, accurately know ideological conditions of teachers and students and utilize effective ways to educate them and improve work quality ${ }^{[3]}$. Finally, the department responsible for network construction for college ideological and political education should fully play the principal role of network, utilize diversified education modes to cultivate students' ideological accomplishment, reduce problems in ideological and political work, innovate education modes and enhance the work effect.

During network construction for college ideological and political education, relevant management personnel must overall analyze network complexity of network according to virtuality and anonymity features of network, formulate sound management system, reduce construction problems of ideological and political education mechanism and improve work quality. Meanwhile, it is also required to actively build a high-quality talent team give play to the positive functions of talents, improve work quality and effectiveness and reduce the adverse effect of religion and decadent ideas on healthy growth of college students ${ }^{[4]}$.

Relevant works in colleges should clearly know their tasks, actively construct the network and enhance management. Firstly, it is necessary to actively explore correct thought and culture, regard healthy thought as the subject of network system, construct characteristic network system by focusing on college work and learning, extend ideological and political education in network under the condition of positive publicity and create a brand-new classroom teaching mode. Meanwhile, it is also required to actively carry out interaction activities, such as establishing open-type email box for campus leaders to guide students to exchange with campus leaders. On the one hand, this is beneficial to the leaders to grasp students' thought. On the other hand, relevant management personnel should create favorable network culture atmosphere, and carry out legal education about information security for teachers or students to make them abide by moral rule. For example, internet security publicity and education activity may be carried out to establish correct internet surfing awareness and legal; awareness for teachers and students and cultivate their concept of responsibility. Besides, campus management personnel and network construction personnel need to scientifically investigate network linking, make sure the construction of each webpage can accord with relevant rules and meet the needs of modern ideological and political education, and improve work quality. Thirdly, the network construction personnel must attach importance to talent team building. Technical personnel are required to fully know theoretical knowledge and technical expertise about network construction for college ideological and political education, overall master all kinds of techniques according to network features and improve education quality. In addition, some part-time education workers may be employed to give certain suggestions so as to improve the work quality. Fourthly, relevant management personnel need to improve safeguard mechanism, scientifically formulate the planning scheme for party building, ideological and political work, bring it into the practical work system and improve network construction management quality under the guidance of college leaders. Fifthly, relevant management personnel need to follow the work rules, overall improve network construction work quality, reduce problems in work and promote work quality and efficiency ${ }^{[5]}$. 


\section{Notes to boost network construction for college ideological and political education}

During network construction for college ideological and political education, colleges must pay attention to its political property, policy and expertise, guarantee technical content, improve network construction quality and reduce the problems.

Firstly, formulate the system of drawing on advantages and avoiding disadvantages. In recent years, some colleges do not draw on advantages, avoid disadvantages, follow network problem handling principles and improve the work quality during network construction for college ideological and political education. Thus, during network construction, colleges must formulate the system of drawing on advantages and avoiding disadvantages, guarantee to improve the application value of network information technology and promote modern network system construction work. For network drawbacks, this is mainly because internet has the features of openness, complex and diversified information, and there is much information adverse to physical and mental development of college students, such as superstition and eroticism which may easily influence their ideological accomplishment. So, relevant management personnel need to establish correct concept for college students, make them able to differentiate harmful information in network and completely eradicate unhealthy ways and customs, and improve quality construction quality.

Secondly, enhance supervision. College management personnel for ideological and political education need to pay attention to network construction work, formulae sound supervision system, strengthen work intensity, utilize sound management methods to carry out education and guidance activities, firm socialism belief, enhance the reform effect of college ideological and political education and reduce the problems.

Thirdly, formulate thorough service system. During network construction for ideological and political education, colleges must formulate thorough service system, exert the function of network education and improve the quality of ideological and political education. At the same time, colleges also should establish patriotic idea and collective idea, integrate the information data beneficial to college development and promote development efficiency. Moreover, management personnel also should formulate sound living service system and learning service system according to ideological characteristics of college students, give play to the network function of answering questions and boost the work quality.

Fourthly, formulate virtual reality education system. After network construction for ideological and political education, colleges must formulate virtual reality education system. The teachers of ideology and politics should participate in relevant activities to better carry out ideological and political education, guide students to correctly deal with all kinds of problems via network, improve work quality, give play to the function of college ideological and political work, accumulate rich work experience, provide beneficial suggestions for management personnel, make sure network construction and management personnel can combine ideological education knowledge, expand network management channels, create favorable learning environment and living environment for college students, exert the function of network ideological education, promote ideological quality of college students and reach the expected purpose.

\section{Conclusions}

College ideological and political education workers must formulate sound management system, actively construct the network, utilize various advanced work modes to reform ideological and political education, meet ideological quality development requirements of college students and improve ideological education work quality.

\section{References}

[1] Wang Yanfei, Study on Network Culture and College Ideological and Political Education, Shanxi Normal University, 2013. 
[2] Zhou Chuan, Liao lei, Zheng Yu et al., Study on Ideological and Political Education Countermeasures Based on Yiban Network Platform, Journal of Chengdu Textile College, 2013,30(4):45-47.

[3] Liu Bojun, College Ideological and Political Education Work Based on Network Age, China and Foreign Exchange, 2016(25):78-78.

[4] Liu Yubai, Innovation Research on Volunteering Activity of University Students as the Carrier of Ideological and Political Education, Anhui University, 2014.

[5] Chen Deqin, Soviet Area Red Culture Explore Some Values in Local Ideological and Political Education: Take Sanming Soviet Area Red Culture as an Example, Journal of Chengdu University of Technology(Social Sciences), 2017,25(1):1-6. 